\title{
Evaluation of Teacher and Student Misbehaviours in Primary Schools from Prospective Teachers' Point of View
}

\author{
Alpaslan Gözler, ${ }^{1, *}$ \\ ${ }^{1}$ Faculty of Education, Erciyes University, Kayseri, Turkey \\ *Correspondence: Faculty of Education, Erciyes University, Kayseri, Turkey. Tel: 90-539-578-2323. E-mail: \\ agozler@erciyes.edu.tr
}

$\begin{array}{ll}\text { Received: October 15, } 2018 & \text { Accepted: November 15, } 2018 \quad \text { Online Published: December 7, } 2018 \\ \text { doi:10.5430/wje.v8n6p11 } & \text { URL: https://doi.org/10.5430/wje.v8n6p11 }\end{array}$

\begin{abstract}
The aim of this study was to evaluate teacher and student misbehaviours and the methods teachers use with regard to student misbehaviours in primary schools from prospective classroom teachers' point of view. The study used phenomenological method, a qualitative research design, since thorough data collection was performed based on personal experiences. The study group consisted of junior ( $3^{\text {rd }}$ grade) students registered for the 2017-2018 academic year in the classroom teaching programme provided by a state university in the Central Anatolia region. 52 prospective classroom teachers participated in the study, on a voluntary basis. While forming the study group, it was intentionally preferred that prospective classroom teachers took the School Experience course. To collect data, a semi-structured interview form was prepared by the researcher. The form included 4 questions on demographic characteristics and 3 questions on the research topic. Data obtained from the study was analyzed by using descriptive analysis, which is widely used in qualitative studies. Certain conclusions were made based on the results obtained from the research. Some of these conclusions can be stated as follows: 1. Some of the most common student misbehaviours in primary schools, according to prospective classroom teachers, are quarrelling with friends, talking without taking permission, complaining, chatting among themselves, and wandering around the classroom. 2. Some of the most common teacher misbehaviours in primary schools, according to prospective classroom teachers, are extreme yelling, constant use of a particular method, discriminating students over one another, and cancelling play and physical activity lesson.
\end{abstract}

Keywords: behaviour, student misbehaviour, teacher misbehaviour, classroom management, prospective classroom teacher

\section{Introduction}

Before addressing explanations on misbehaviours, it is necessary first to define behaviour and misbehaviour. Charles (1992) defines behaviour as good-bad, right-wrong, useful-useless and physical-mental actions displayed by people. He defines misbehaviour as a conscious conduct that is not appropriate for a situation or setting (as cited in Pala, 2005).

It can be noted that there is intimate communication in school settings where educational activities are conducted, and thus, behaviours gain particular importance in these places. The most important learning setting in school is classroom. Classroom management is essential for conducting teaching and learning activities in an effective manner. Classroom management can be defined as the organization of classroom environment pedagogically, managerially and strategically (Yılmaz, 2012).

The most important factor for the development and improvement of the societies is education. Importance and requirement of the education increase day by day. Education process is a whole of actions which tries to raise the qualified person (Pepe, Turan, Pekel, Bahadır, 2015). Establishing order is inevitable to achieve efficiency in schools and classrooms where education activities are carried out. Edwards (1993) asserts that maintaining order is one of the most important duties of teachers. Just as maintaining this order helps to provide students with intended behaviours, it is also a natural outcome that undesirable behaviours can also arise in schools (Gökden Kaya and Ataman, 2017).

As the most important element of school organization and classroom management (Başar, 1997; Balay, 2003), 
teachers play a major role in equipping students with desirable and undesirable qualities. Also, teachers assume significant tasks in attaining the goals of instruction process. One of these roles is creating a favourable classroom atmosphere (Akgün, Yarar and Dinçer, 2011). Unwanted behaviours seen in classroom settings that host a substantial part of teaching and learning activities have a negative impact on time and classroom management, particularly on teaching process. It is no doubt that teachers have a significant role in hindering such behaviours and organizing instruction environment (Çetin, 2013). Relationships in classroom transform into experiences, and a social environment is created in the classroom. It can be assumed normal that both positive and negative behaviours can be seen in this environment (Çarpi, Balcı and Çelikkaleli, 2010). Considering that correcting and changing negative behaviours as well as introducing positive behaviours form the basis of education (Sarıtaş, 2006), misbehaviours present themselves as an important issue in the system.

Misbehaviour can be defined as a conduct that impedes educational and training activities as well as students' learning, disrupts learning environment directly or indirectly, and creates disorder (Edwards, 1993; Başar, 1997; Tertemiz, 2000; Sadık and Doğanay, 2007). In addition, all actions that hinder educational efforts at school can be defined as misbehaviour (Çetin, 2013). Charles and Senter (2005) characterize student misbehaviour as in-school and in-class behaviours that generate negative outcomes such as hindering instruction, reducing students' motivation and creating a problematic environment for both students and teachers (as cited in Özbilen, Canbulat and Soylu, 2017).

The frequency and degree of student misbehaviours vary across schools and class environment. Some of the reasons include teachers' knowledge of and skills in classroom management, sex and marital status (Tanhan and Şentürk, 2011; Konur and Birinci Konur, 2014; Cebeci and Şirin, 2017).

The most common student misbehaviours in classroom can be stated as chatting among themselves, disturbing classmates, speaking without permission, yelling at classmates, dealing with other stuff, being disrespectful, use of slang, cheating, untidiness, wandering around the classroom without permission, failure to bring course materials and humiliating classmates (Cameron, 1998; Baloğlu, 2001; Erdoğan, 2002; Kee Tony, 2003; Özdemir, 2004; Pala, 2005; Sarıtaş, 2006; Ercan, 2017; Özdemir, 2017; Toprakçı, 2017). According to Charles (1992), disruptive misbehaviours perceived by teachers are assault, indecency, disobedience to authority, disrespect and wasting time (as cited in Pala, 2005).

Misbehaviours in school and classroom are mostly considered as student behaviours in literature. However, teacher misbehaviours in classroom and school also have considerable impact on instruction and learning environment. Examples of teacher misbehaviour in classroom are discussed in literature as follows: discriminating students over one another, giving too much homework, intimidating students with grade, insulting and humiliating students, use of sentences not appropriate for students' level, constant use of a particular method-technique, lateness to class, consistently being tough on students, and constant punishment of students (Turanl1, 1995; Tertemiz, 2000; Çetin, 2001; Güçlü, 2003; Mursal, 2005; Seniye, 2007).

Teaching environments can be improved in terms of technology and infrastructure for style selection and self-definition can be increased (Turan, Koç, 2018). Atıcı (2001) maintains that when creating a learning environment, teachers should manage student behaviours as well as instruction methods. Strategies for coping with misbehaviour are addressed differently in different sources. While they are classified as punitive, remedial and preventive strategies (Aslan, Dündar, Alptekin and Saraç, 2011), they are also categorized under separate titles such as verbal warning and communication (Uğurlu, Doğan, Şöförtakımcı, Ay and Zorlu, 2014). Education environments with which participants can express themselves comfortable can be created ( Turan, Koç, Karaoğlu, 2017).

Martin, Linfoot and Stephenson (1999) state that the following strategies are used by teachers to respond to misbehaviour: positive strategies, non-physical punishment, transferring students to other school staff and receiving professional help outside the school (as cited in Uysal, Akbaba Altun and Akgün, 2010). In his study, Sadık (2008) indicates that teachers develop preventive and remedial strategies against unwanted student behaviours. In addition, the results of observation indicated that verbal warning is the most widely used strategy in classroom.

There are various study results for the reasons of misbehaviours in class. For instance, the result of a study by Çelikkaleli, Balcı, Çarpi and Büte (2009) indicate that the most important reasons for misbehaviour among primary school students are personal characteristics, family characteristics and socio-economic conditions. On the other hand, Sadık (2008) maintains that some student misbehaviours in class are passive engagement in class and failure to participate in class activities. Thus, it is considered that teachers also influence student misbehaviours.

Student misbehaviours in school have been a topic that has been discussed in educational sciences for many years. Studies on the subject have concentrated on primary schools and research has been conducted based on 
student-teacher views (e.g. Geiger, 2000; Atc1, 2004; Sadık and Doğanay, 2007; Balay and Sağlam, 2008; Kocabey, 2008; Sadık, 2008; Elban, 2009; Alkaş, 2010; Çapri, Balcı and Çelikkaleli, 2010; Tanhan and Şentürk, 2011; Çetin, 2013; Özdaş, 2013; Ekici and Ekici, 2014; Şahin and Arslan, 2014; Aküzüm and Nazlı, 2017; Cebeci and Şirin, 2017; Gökden Kaya and Ataman, 2017; Güder, Alabay and Güner, 2018). Furthermore, studies on teacher misbehaviour, few though, started to be conducted by referring to student views in recent years (Güzel, 2017; Yeşilyurt, 2017). Thus, misbehaviour in primary schools is mostly discussed as student behaviours, and study groups in such research comprise students and teachers. Moreover, studies on teacher misbehaviour are scanty. This study evaluated both student and teacher misbehaviours in primary schools and the methods used by teachers to respond to student misbehaviours from the perspective of prospective classroom teachers. In this respect, it is an important study.

The aim of this study was to assess student and teacher misbehaviours and methods employed by teachers to respond to student misbehaviours in primary schools based on the views of prospective classroom teachers.

To that end, the study attempted to provide answers to the following questions:

1. What are teacher misbehaviours in primary schools according to classroom teachers?

2. What are student misbehaviours in primary schools according to classroom teachers?

3. What methods are used by classroom teachers to respond to student misbehaviours in primary schools according to classroom teachers?

\section{Method}

\subsection{Research Design}

This is a qualitative study aimed at assessing student and teacher misbehaviours and the methods used by teachers against student misbehaviour in primary schools based on the views of prospective classroom teachers. The study used phenomenological method, a qualitative research design since thorough data collection was performed based on individual experiences (Creswell, 2007; Glesne, 2013; Saban and Ersoy, 2016; Yıldırım and Şimşek, 2016). The fact that prospective classroom teachers comprising the study group made observations and gained experience in primary schools as part of the School Experience course made the use of this method necessary. According to Mertens (2010), participants' experiences are crucial in phenomenological design.

\subsection{Study Group}

The study group consisted of $3^{\text {rd }}$ grade students in the department of classroom teaching at a state university in Central Anatolia in the 2017-2018 academic year. A total of 52 prospective classroom teachers participated in the study on a voluntary basis. In selecting the study group, it was intentionally preferred that prospective teachers took the School Experience course. Demographic characteristics of the participants are given in Table 1.

Table 1. Demographic Characteristics of Participants

\begin{tabular}{llll}
\hline Type & Variable & Frequency (f) & $\begin{array}{l}\text { Percentage } \\
(\mathbf{\%})\end{array}$ \\
\hline \multirow{2}{*}{ Gender } & Female & 43 & 82.7 \\
& Male & 9 & 17.3 \\
\hline \multirow{3}{*}{ Grade observed } & 1 & 14 & 26.9 \\
& 2 & 17 & 32.7 \\
\hline Gender of classroom teacher & 3 & 10 & 19.2 \\
observed & 4 & 11 & 21.2 \\
\hline \multirow{3}{*}{ Experience of classroom teacher } & Female & 18 & 34.6 \\
observed & Male & 34 & 65.4 \\
& $1-8$ years & 5 & 9.6 \\
& $9-16$ years & 13 & 25.0 \\
\hline & $17-24$ years & 20 & 38.5 \\
& $25+$ years & 14 & 26.9 \\
\hline
\end{tabular}

An analysis of Table 1 demonstrated that $82.7 \%$ (43) of the prospective classroom teachers who took part in the study were female and $17.3 \%$ (9) were male. It was also found that $26.9 \%$ (14) of the classrooms observed as part of 
the School Experience course was $1^{\text {st }}$ grade, $32.7 \%(17) 2^{\text {nd }}$ grade, $19.2 \%(10) 3^{\text {rd }}$ grade and $21.2 \%(11) 4^{\text {th }}$ grade. Besides, of the classroom teachers observed, 34.6\% (18) were female and $65.4 \%$ (34) were male while 9.6\% (5) had 1-8 years' experience, $25.0 \%$ (13) 9-16 years, $38.5 \%$ (20) $17-24$ years and $26.9 \%$ (14) $25+$ years' experience.

\subsection{Data Collection Process}

To collect data for the study, a semi-structured interview form was drafted by the researcher. For this purpose, the relevant literature was reviewed and the form was prepared. Then, after receiving the opinion of an educationalist, the form was finalized. In the end, the form included four questions on demographic characteristics and three questions on the research topic. It was used to take the views of prospective classroom teachers in the study group. The study data was collected at different times when the respondents were available. It was declared that the data on the participants and schools that were observed as part of the School Experience course would not be shared with third parties and would only be used for this study. The answers given by the prospective teachers in the interview form constituted the data set of the study.

\subsection{Data Analysis}

The data obtained from the research was analysed through descriptive analysis method, a widely used qualitative research design. Yıldırım and Şimşek (2016) state that data can be organized, in descriptive analysis, according to the themes suggested in research questions as it can also be presented by taking into consideration the questions or dimensions used in the interviewing processes. In this type of analysis, researcher makes extensive use of exact quotations to better reflect the opinions of participants in the study group. Descriptive analysis is a qualitative data analysis method that involves the interpretation of data according to predetermined themes (Özdemir, 2010). The themes of this study consisted of sub-problems of the study. Categories given under these themes were created based on the respondents' views, and presented with percentage and frequency values.

\section{Findings}

This section presents findings based on the sub-problems of the study. Student and teacher misbehaviours in primary schools and the methods used by teachers to respond to such behaviours are given in tables in order. Student misbehaviours as perceived by prospective classroom students in primary schools are listed in Table 2 .

Table 2. Student Misbehaviours in Primary Schools According to Prospective Classroom Teachers

\begin{tabular}{llll}
\hline Item No & Student Misbehaviour & f & $\mathbf{\%}$ \\
\hline 1 & Quarrelling with classmates & 28 & 15,5 \\
2 & Talking without permission & 21 & 11,6 \\
3 & Snitching (complaining) & 17 & 9,4 \\
4 & Chatting among themselves & 16 & 8,8 \\
5 & Wandering around the classroom & 16 & 8,8 \\
6 & Playing games that might hurt each other & 12 & 6,6 \\
7 & Excluding foreign classmates & 11 & 6,1 \\
8 & Disrespectful conducts & 10 & 5,5 \\
9 & Interrupting each other & 9 & 4,9 \\
10 & Failure to bring course materials to the class & 7 & 3,9 \\
11 & Constant crying (for simple reasons) & 6 & 3,3 \\
12 & Practical jokes & 5 & 2,8 \\
13 & Consistently asking permission to go the toilet & 5 & 2,8 \\
14 & Use of slang & 4 & 2,1 \\
15 & Paying no attention to class hours & 3 & 1,7 \\
16 & Damaging school equipment & 3 & 1,7 \\
17 & Asking to stay with the teacher & 3 & 1,7 \\
18 & Mistreating mainstreaming students & 2 & 1,1 \\
19 & Refusing to apologize for a mistake & 2 & 1,1 \\
20 & Lying & 1 & 0,6 \\
Total & & $\mathbf{1 8 1}$ & $\mathbf{1 0 0}$ \\
\hline
\end{tabular}


According to Table 2, prospective classroom teachers who took part in the study stated that there are 20 different student misbehaviours in primary schools. The most widely expressed misbehaviours are quarrelling with friends (28), talking without permission (21), complaining (17), chatting among themselves (16), wandering around the classroom (16), playing games that might hurt each other (12), excluding foreign classmates (11), disrespectful conducts (10) and interrupting each other (9). The least expressed student misbehaviours are paying no attention to class hours (3), damaging school equipment (3), asking to stay with the teacher (3), mistreating mainstreaming students (2), refusing to apologize for a mistake (2) and lying (1). Some examples from the prospective classroom teachers' statements are given below:

F.1: Most students always quarrel among themselves in break time. They quarrel and fight to the extent that they could hurt each other. Besides, most students do not include foreign students in their games etc. in break time.

F.19: Students are competing with each other to find their peers' deficiency and tell it to the teacher. They always try to interrupt the lesson.

M.38: Some students do not bring course materials to school. They play practical jokes during break, and as a result, joke turns into fight.

F.51: There are some students in $1^{\text {st }}$ grade who are crying all the time. They cry especially in the first hours or just cry over a trivial thing. They want to have what they ask. The teacher cannot help but call their parents. There are student who cannot get used to school although the academic year is going to end soon.

Table 3 demonstrates teacher misbehaviours as perceived by the prospective classroom teachers in primary schools.

Table 3. Teacher Misbehaviours in Primary Schools According to Prospective Classroom Teachers

\begin{tabular}{llll}
\hline Item No & Teacher Misbehaviour & f & $\mathbf{\%}$ \\
\hline 1 & Excessive yelling & 20 & 15,2 \\
2 & Constant use of a particular method & 16 & 12,1 \\
3 & Discriminating students over one another & 13 & 9,8 \\
4 & Cancelling play and physical activity (physical education) lesson & 13 & 9,8 \\
5 & Insulting students & 9 & 6,8 \\
6 & Sitting at table all the time & 8 & 6,1 \\
7 & Making students stand as punishment & 7 & 5,3 \\
8 & Lateness to class & 7 & 5,3 \\
9 & Sending students out of class as punishment & 6 & 4,5 \\
10 & Being emotional & 5 & 3,8 \\
11 & Not paying attention to mainstreaming students & 5 & 3,8 \\
12 & Leaving class often for talking on phone & 5 & 3,8 \\
13 & Suppressing gifted students & 4 & 3,0 \\
14 & Being too tough on shifts & 3 & 2,3 \\
15 & Telling students' personal problems (health etc.) in class & 3 & 2,3 \\
16 & Giving bright students less opportunity to speak & 3 & 2,3 \\
17 & Using reading as punishment & 3 & 2,3 \\
18 & Not paying attention to foreign national students & 2 & 1,5 \\
Total & & $\mathbf{1 3 2}$ & $\mathbf{1 0 0}$ \\
\hline
\end{tabular}

As is seen in Table 3, the participants of the study expressed 18 different teacher misbehaviours in primary schools. The most commonly reported teacher misbehaviours are excessive yelling (20), constant use of a particular method (16), discriminating students over one another (13), cancelling play and physical activity lesson (13), insulting students (9) and sitting at table all the time (8). The least reported teacher misbehaviours are suppressing gifted students (4), being too tough on shifts (3), telling students' personal problems in class (3), giving bright students less opportunity to speak (3), using reading as punishment (3) and not paying attention to foreign students (2).

F.9: The classroom teacher yells at kids too much when they chat. However, he does so for maintaining silence in the classroom. He makes students who have not brought their books wait near the dustbin.

M.27: The teacher suppresses gifted students, saying that you may know (the subject), but wait. When he does it all the time, students get discouraged. In addition, when students misbehave or do not make their homework, etc., he cancels physical education (play and physical activities) lesson, and teaches another one. 
F.33: Our teacher always sits at his table instead of wandering in the class, and thus, cannot notice the condition of students sitting at the back of the class. Besides, he sometimes comes to class late. When his phone rings during the lesson, he answers it instantly.

M.43: The teacher teaches monotonously, without resorting to diverse instruction methods and techniques, which results in students' getting bored and conversing among themselves. So, he gets very angry and resents students.

Table 4 presents the methods employed by classroom teachers to respond to student misbehaviours in primary schools according to the prospective classroom teachers' viewpoint.

Table 4. Methods Used by Classroom Teachers against Student Misbehaviours in Primary Schools According to Prospective Classroom Teachers

\begin{tabular}{llll}
\hline Item No & $\begin{array}{l}\text { Methods Used by Classroom Teachers to Respond to Student } \\
\text { Misbehaviours }\end{array}$ & f & \% \\
\hline 1 & Verbal warning & 35 & 17,2 \\
2 & Punishment (standing, not letting to take a break, etc.) & 28 & 13,8 \\
3 & Warning in anger & 17 & 8,4 \\
4 & Warning with body language (eye contact, approaching, etc.) & 17 & 8,4 \\
5 & Changing the student's seat & 13 & 6,4 \\
6 & Raising the tone of voice & 11 & 5,4 \\
7 & Talking to student & 10 & 4,9 \\
8 & Cancelling play and physical activity lesson & 9 & 4,4 \\
9 & Reminding the rules & 9 & 4,4 \\
10 & Making the student apologize & 8 & 3,9 \\
11 & Talking with the student outside the classroom & 7 & 3,4 \\
12 & Ignoring & 7 & 3,4 \\
13 & Use of reinforcers & 6 & 3,0 \\
14 & Complaining to family & 5 & 2,5 \\
15 & Assigning tasks & 5 & 2,5 \\
16 & Asking students to solve (problems) among themselves & 5 & 2,5 \\
17 & Not allowing the student to speak & 4 & 2,0 \\
18 & Wandering in the classroom all the time & 4 & 2,0 \\
19 & Asking questions to engage students in the class & 3 & 1,5 \\
Total & & $\mathbf{2 0 3}$ & $\mathbf{1 0 0}$ \\
\hline
\end{tabular}

According to Table 4, the respondents indicated 19 different methods used by classroom teachers against student misbehaviours in primary schools. The most commonly reported methods are verbal warning (35), punishment (28), warning in anger (17), warning with body language (17), changing student's seat (13), raising the tone of voice (11), talking to student (10), cancelling play and physical activity lesson (9) and reminding the rules (9). The least reported methods are complaining to family (5), assigning tasks (5), asking students to solve (problems) among themselves (5), not allowing the student to speak (4), wandering in the classroom all the time (4) and asking questions to engage students in the class (3). Some examples of the statements made by the respondents are given below:

M.11: The teacher warns students who misbehave or talk during the lesson more. When such behaviours are repeated, he makes them stand near the dustbin or does not let them out during break time. He informs family in certain cases such as fighting.

F. 15: The teacher we observed is quite relaxed in the class. He overlooks some of the problematic behaviours. When students complain each other or fight, he makes them apologize to each other or to the class. He uses body language very well, such as glaring etc. However, he adopts a positive attitude most of the time. He motivates students, for example by saying that my boy is smart, he does not misbehave or speak without permission, etc.

F. 36: You can witness problem behaviours in class almost all the time. However, the teacher prevents them very well. For example, he wanders around the class, approaches problematic students, looks at them when teaching or asks questions instantly. Sometimes, he assigns duties to these students such as cleaning the board and hanging stuff on board. He mostly asks students to solve their complaints among themselves. I think his methods are good. 
F. 48: In the case of undesirable behaviours in class, the teacher raises his voice, becomes angry with the student in question or talks to the student outside the classroom. Occasionally, he changes some students' seats to separate students who get along well or cause problems.

\section{Discussion and Conclusion}

One of the primary stakeholders in teaching and learning activities is teacher and students. It is a fact that the main objective is to educate students and this job is done by teachers directly. To conduct teaching and learning activities on a sound basis, it is of importance to recognize student and teacher misbehaviours in school and classroom that will damage the process, and to make efforts to eliminate such behaviours. When considered from this point of view, it was deemed important the observation of student and teacher misbehaviours in primary schools by prospective classroom teachers who will be teaching in the classroom in the future as independent observers, and this study was conducted.

The results of the study revealed that the most common student misbehaviours in primary schools are fighting with classmates, talking without permission, complaining, chatting among themselves, wandering around the classroom, playing games that might hurt each other, excluding foreign classmates, disrespectful conduct and interrupting each other. Other student misbehaviours include failure to bring course materials, constant crying, practical jokes, use of slang, constantly asking permission to go the toilet, paying no attention to class hours, damaging school equipment, asking to stay with the teacher, mistreating mainstreaming students, refusing to apologize for a mistake and lying.

A review of literature indicates that the most common student misbehaviours in the classroom environment are chatting among themselves, disturbing classmates, talking without permission, yelling at classmates, dealing with other stuff, being disrespectful, use of slang, cheating, untidiness, wandering around the classroom without permission, failure to bring course materials to school, humiliating classmates and cheating (Cameron, 1998; Baloğlu, 2001; Erdoğan, 2002; Kee Tony, 2003; Özdemir, 2004; Pala, 2005; Sarıtaş, 2006; Ercan, 2017; Özdemir, 2017; Toprakç1, 2017). It is seen that the results in literature support the results of this study substantially. While the occurrence of student misbehaviours in the classroom is considered normal (Gökden Kaya and Ataman, 2017), it is recommended for teachers to use effective methods in order not to allow such misbehaviours affect teaching and learning process negatively. In addition, we believe that knowing the causes of student misbehaviours identified at the end of the study will contribute to the prevention of these behaviours. Thus, it is suggested that more scientific studies should be conducted to explore the causes of student misbehaviour.

According to the statements of the prospective classroom teachers who participated in the study, the most reported teacher misbehaviours ns primary schools are excessive yelling, constant use of a particular method, discriminating students over one another, cancelling play and physical activity lesson, insulting students, sitting at the table all the time, making students stand as punishment and lateness to class. Other teacher misbehaviours include sending students out of the classroom as punishment, being emotional, not paying attention to mainstreaming students, leaving the classroom often for phone conversation, suppressing gifted students, being too tough on shifts, telling students' personal problems in class, giving bright students less opportunity to speak, use of reading as a punishment and not paying attention to foreign students. Although the studies on teacher misbehaviour are not abundant in literature, teacher misbehaviours in the existing sources include discriminating between students, giving too much homework, intimidating students with grades, insulting and humiliating students, use of sentences not appropriate for students' level, teaching with a particular method-technique all the time, lateness to class, consistently being tough on students and constant punishment of students (Turanl, 1995; Tertemiz, 2000; Çetin, 2001; Güçlü, 2003; Mursal, 2005; Seniye, 2007). The results of this study are similar to the relevant literature concerning several misbehaviours and particularly constant punishment.

The most striking result of the study was the use of reading as a punishment by the teachers. In a time when many studies and projects are carried out to make students love reading and read, the use of reading as a punishment is considered a negative outcome. Given that primary school period is accepted as an important stage in preparing students for life and an upper educational level, misbehaviours displayed by classroom teachers in this period will negatively affect teaching and learning process. Therefore, it is recommended to conduct necessary trainings and tighter inspection at schools for eliminating these teacher misbehaviours.

Considering that student misbehaviours in classroom where a substantial part of teaching and learning activities are held have a negative impact on both instruction process and classroom management, it is known that teachers play a significant role in preventing such behaviours (Atıc1, 2001; Çetin, 2013). Thus, the methods used by teachers to respond to undesirable student behaviours are also important. According to the participants in the study, the methods 
most commonly used by classroom teachers against student misbehaviours in primary schools are verbal warning, punishment, warning in anger, warning with body language, changing the student's seat, raising the tone of voice, talking to the student, cancelling play and physical activity class, reminding the rules and making students apologize. Other methods employed by teachers include talking to the student outside the classroom, ignoring, use of reinforcers, complaining to the family, assigning tasks, asking students to solve (the problem) among themselves, not letting the student speak, wandering around the classroom constantly and addressing questions to engage the student in the class. Martin, Linfoot and Stephenson (1999) indicate that the methods used by teachers to respond to student misbehaviours are the use of positive strategies, nonphysical punishment, sending the student to other school staff and seeking professional help outside the school (as cited in Uysal, Akbaba Altun and Akgün, 2010). Aslan, Dündar, Alptekin and Saraç (2011) classify these strategies as punitive, remedial and preventive strategies. Another study lists them under different categories such as verbal warning and communication (Uğurlu, Doğan, Şöförtakımcı, Ay and Zorlu, 2014). On the other hand, Sadık (2008) asserts that teachers develop preventive and remedial strategies against unwanted student behaviours while verbal warning is the most widely used strategy in the classroom.

\section{Recommendations}

The findings of this study were also consistent with the methods employed by teachers to respond to student misbehaviours in literature. However, cancelling play and physical activity lesson, a method used by teachers according to the results of the study, can be assessed as a negative outcome. Indeed, since cancelling a lesson as a method will disrupt the instruction process, it can be deemed an unacceptable situation. Furthermore, it is recommended that the methods and strategies that should be used by classroom teachers to respond to student misbehaviours can be integrated into trainings as a seminar topic. Besides, in a time when we live with technology to such extents, the Ministry of Education or directorates of national education can design a website introducing the strategies that can be used to respond to misbehaviour for the use of teachers.

\section{References}

Akgün, E., Yarar, M., \& Dinçer, Ç. (2011). Okul öncesi öğretmenlerin sınıf içi etkinliklerde kullandıkları sınıf yönetimi stratejilerinin incelenmesi. Pegem Eğitim ve Öğretim Dergisi, 1(3), 1-9. https://doi.org/10.14527/C1S3M1

Aküzüm, C., \& Nazlı, D. K. (2017). Sınıf Öğretmenlerinin sınıf yönetiminde karşılaştıkları disiplin sorunları, nedenleri ve bu sorunlarla baş etme yöntemlerinin değerlendirilmesi. International e-Journal of Educational Studies, 1(2), 88-101.

Alkaş, B. (2010). İlköğretim ögrrencileri arasındaki istenmeyen öğrenci davranışlarının incelenmesi. Unpublished master's thesis. Ankara Üniversitesi Eğitim Bilimleri Enstitüsü, Ankara.

Aslan, Ş., Dündar, U., Alptekin, A., \& Saraç, N. (2011). Öğretmenlerin beden eğitimi dersinde ortaya çıan istenmeyen davranışlara karşı kullandıkları yöntemler. Yüzüncü Yll Üniversitesi Eğitim Fakültesi Dergisi, Ulusal Beden Eğitimi ve Spor Öğrt. Kongresi Özel Saylsı, 46-51.

Atc1, A. (2004). İlköğretim 1. kademe öğretmenlerinin sınıf içi problem davranışlara yönelik müdahalelerinin incelenmesi. Unpublished master's thesis. Çukurova Üniversitesi Sosyal Bilimler Enstitüsü, Adana.

Atıcı, M. (2001). Yüksek ve düşük yetkinlik düzeyine sahip öğretmenlerin sınıf yönetimi stratejileri. Kuram ve Uygulamada Eğitim Yönetimi Dergisi, 7(4), 483-499.

Balay, R., \& Sağlam, M. (2014). Sınıf içi olumsuz davranışlara ilişkin öğretmen görüşleri. Yüzüncü Yll Üniversitesi Eğitim Fakültesi Dergisi, 5(2), 1-24.

Baloğlu, N. (2001). Etkili sinıf yönetimi. Ankara: Baran Ofset.

Başar, H. (1997). Sinıf yönetimi. Ankara: Pegem A Yayıncılık.

Cameron, R. J. (1998). School discipline in the United Kingdom: Promoting classroom behaviour which encourages effective teaching and learning. School Psychology Review, 27, 33-44.

Çapri, B., Balcı, A., \& Çelikkaleli, Ö. (2010). İlköğretim öğretmenlerinin sınıf içi istenmeyen davranışlara ilişkin görüşlerinin karşılaştırılması. Mersin Üniversitesi Eğitim Fakültesi Dergisi, 6(2), 89-102.

Cebeci, B., \& Şirin, T. (2017). İlköğretim kurumlarında öğrencilerin istenmeyen davranışlarına dair öğretmen tutumlarının çeşitli değişkenler açısından incelenmesi. International Journal of Contemporary Educational 
Studies, 3(1), 13-33.

Çelikkaleli, Ö., Balcı, F. A., Çapri, B., \& Büte, M. (2009). Teacher views on the sources of students' misbehaviours at primary schools. Elementary Education Online, 8(3), 625-636.

Çetin, B. (2013). Sınıfta istenmeyen öğrenci davranışlarıyla ilgili sınıf öğretmenlerinin karşılaştıkları sorunlar ve çözüm önerileri. Ahi Evran Üniversitesi Kırşehir Eğitim Fakültesi Dergisi, 14(1), 255-269.

Çetin, Ş. (2001). İdeal Öğretmen Üzerine Bir Araştırma. Milli Eğitim Dergisi, 149.

Creswell, J. W. (2007). Qualitative inquiry and research design: Choosing among five traditions. Thousand Oaks, CA: Sage.

Edwards, C. H. (1993). Classroom discipline and management. Newyork: Macmillan Publishing Company.

Ekici, R., \& Ekici, A. (2014). Sınıf yönetiminde istenmeyen öğrenci davranışlarının ilkokul ve ortaokullarda karş1laştırmalı incelenmesi. Ekev Akademi Dergisi, 59, 107-118.

Elban, L. (2009). İlköğretimdeki öğretmenlerin istenmeyen ögrrenci davranışlarıyla karşılaşma ve çözüm bulma durumlarının incelenmesi. Unpublished master's thesis. Selçuk Üniversitesi Sosyal Bilimler Enstitüsü, Konya.

Ercan, L. (2017). Sinıfta istenmeyen davranışların yönetimi. In G. Yüksel ve S. Büyükalan Filiz (Ed.). Ankara: Pegem Akademi Yayınc1lik. https://doi.org/10.14527/9786052410905.09

Erdoğan, İ. (2002). Sinıf yönetimi. İstanbul: Sistem Yayıncılık.

Geiger, B. (2000). Discipline in through 8th grade classrooms. Education, 121(2), 383-394.

Glesne, C. (2013). Nitel araştırmaya giriş. Ersoy, A., \& Yalçınoğlu, P. (Çev. Ed.). Ankara: Anı Yayıncılık.

Gökden Kaya, N., \& Ataman, A. (2017). Üstün yetenekli öğrencilerin istenmeyen davranışlarına yönelik öğretmenlerin eğitim ihtiyaçlarının belirlenmesi. Gazi University Journal of Gazi Educational Faculty (GUJGEF), 37(3), 835-853.

Güçlü, N. (2003). İletişim. Sınıf Yönetimi (Ed. L. Küçükahmet). Ankara: Nobel Yayın Dağıtım.

Güder, S. Y., Alabay, E., \& Güner, E. (2018). Okul öncesi öğretmenlerinin sınıflarında karşılaştıkları davranış problemleri ve kullandıkları stratejiler. Ilkögretim Online, 17(1), 414-430. https://doi.org/10.17051/ilkonline.2018.413792

Güzel, H. (2017). Lise öğrencilerinin istenmeyen öğretmen davranışlarına yönelik algılarının incelenmesi. Selçuk Üniversitesi Sosyal Bilimler Enstitüsü Dergisi, 38, 209-220.

Kee Tony, T. S. (2003). Locus of control, attributional style and discipline problems in secondary schools. Early Child Development and Care, 173(5), 455-466. https://doi.org/10.1080/0300443032000088203

Kocabey, A. (2008). 2005 ilköğretim programının uygulanması sirasında sını öğretmenlerinin sinıfta karşılaştıkları istenmeyen ögrenci davranışları. Unpublished master's thesis. Çukurova Üniversitesi Sosyal Bilimler Enstitüsü, Adana.

Konur, B., \& Birinci Konur, K. (2014). Sınıf ortamında istenmeyen öğrenci davranışlarına karşı öğretmen stratejileri. Akademik Sosyal Araştırmalar Dergisi, 2(8), 219-232.

Mertens, D. (2010). Research and evaluation in education psychology. Los Angeles: Sage Publications.

Mursal, E. (2005). İlköğretim I. kademe 5. sinıf öğrencilerinin sinıf içerisinde istenmeyen davranışlar göstermesine neden olan öğretmen davranışlarına ilişkin ögrretmen ve ögrenci görüşleri. Yayımlanmamış yüksek lisans tezi. Abant İzzet Baysal Üniversitesi Sosyal Bilimler Enstitüsü, Bolu.

Özbilen, F. M., Canbulat, T., \& Soylu, Y. (2017). Okul zorbalığı ve sınıf içi istenmeyen davranışlara ilişsin öğretmen tutumlarının değerlendirilmesi. Türk Psikolojik Danışma ve Rehberlik Dergisi, 7(47), 1-15.

Özdaş, F. (2013). Ortaokullarda değerler eğitimi ve istenmeyen öğrenci davranışlarına iliş̧kin öğretmen görüşlerinin değerlendirilmesi. Yayımlanmamış doktora tezi. Fırat Üniversitesi Eğitim Bilimleri Enstitüsü, Elazığ.

Özdemir, İ. E. (2004). Sinıf ortamında istenmeyen davranışlar. Sınıf yönetimi (Ed: Ş. Erçetin ve M. Ç. Özdemir). Ankara: Asil Yayın Dağıtım.

Özdemir, İ. E. (2017). Sınıf ortamında istenmeyen davranışlar ve yönetimi. Sınıf yönetimi (Ed. M. Ç. Özdemir). Ankara: Pegem Akademi Yayıncılık. https://doi.org/10.14527/9786053641803

Özdemir, M. (2010). Nitel veri analizi: Sosyal bilimlerde yöntembilim sorunsalı üzerine bir çalışma. Eskişehir 
Osmangazi Üniversitesi Sosyal Bilimler Dergisi, 11(1), 323-343.

Pala, A. (2005). Sınıfta istenmeyen öğrenci davranışlarını önlemeye dönük disiplin modelleri. Manas Üniversitesi Sosyal Bilimler Dergisi, 13, 171-179.

Pepe, O., Turan M.B., Pekel A., Bahadır, Z. (2015). Investigation of Self-Reported Teaching Style Preferences and Perceptions of Physical Education and Sport Teacher Candidates, International Journal of Science Culture and Sport (IntJSCS), Special Issue 3, 116-124. https://doi.org/10.14486/IJSCS267

Saban, A., \& Ersoy, A. (2016). Eğitimde nitel araştırma desenleri. Ankara: Anı Yayıncılık.

Sadık, F. (2008). The investigation of strategies to cope with students' misbehaviors according to teachers and students' perspectives. Elementary Education Online, 7(2), 232-251.

Sadık, F., \& Doğanay, A. (2007). Sınıf içi istenmeyen davranışlarla ilgili öğretmen öğrenci ve veli görüşlerinin karşılaştırılması. Çukurova Üniversitesi Sosyal Bilimler Enstitüsü Dergisi, 16(1), 539-560.

Şahin, S., \& Arslan, M. C. (2014). Öğrenci ve öğretmen görüşlerine göre istenmeyen öğrenci davranışlarına karş1 kullanılan öğretmen stratejilerinin öğrenciler üzerindeki etkileri. Turkish Studies-International Periodical for the Languages, Literature and History of Turkish or Turkic, 9(2), 1399-1415.

Sarıtaş, M. (2006). Öğretmen adaylarının değerlendirmelerine göre sınıfta istenmeyen öğrenci davranışlarını değiştirmek ve düzeltmek amacıyla yararlanılan stratejiler. Uludă̆ Üniversitesi Eğitim Fakültesi Dergisi, 19(1), 167-187.

Seniye, V. (2007). Öğretmenlerin ve öğrencilerin güdüleyici öğretmen davranışları hakkındaki algıları. Yayımlanmamış yüksek lisans tezi. Bilkent Üniversitesi Eğitim Bilimleri Enstitüsü, Ankara.

Tanhan, F., \& Şentürk, E. (2011). Sınıf içi istenmeyen öğrenci davranışlarına yönelik öğretmen tutumlarının bazı sosyo-demografik değişkenler açısından incelenmesi. Milli Eğitim Dergisi, 41(192), 62-73.

Tertemiz, N. (2000). Sinıf yönetimi ve disiplin. Sınıf Yönetimi In (L. Küçükahmet Ed.,). Ankara: Nobel Yayıncılık.

Toprakçı, E. (2017). Sinıf yönetimi. Ankara: Pegem Akademi Yayıncılık. https://doi.org/10.14527/9786053644583

Turan, M.B., \& Koç, K. (2018). Examination of the Effect of the Instructional Styles of Pre-Service Physical Education and Sports Teachers on the Ability of Self-Regulation. Asian Journal of Education and Training, 4(4), 302-308. https://doi.org/10.20448/journal.522.2018.44.302.308

Turan, M.B., Koç, K., \& Karaoğlu, B. (2017). Analysis of Ego Identity Status of School of Physical Education and Sports. Universal Journal of Educational Research, 5(9), 1580-1588. https://doi.org/10.13189/ujer.2017.050915

Turanl, A. S. (1995). Students' expectations and perceptions of teachers' classroom management behaviors. Yayımlanmamış Yüksek Lisans Tezi. ODTÜ Sosyal Bilimler Enstitüsü, Ankara.

Uğurlu, C. T., Doğan, S., Şöförtakımcı, G., Ay, D., \& Zorlu, H. (2014). Öğretmenlerin sınıf ortamında karşılaştıkları istenmeyen davranışlar ve bu davranışlarla baş etme stratejileri. Turkish Studies - International Periodical For The Languages, Literature and History of Turkish or Turkic, 9(2), 577-602.

Uysal, H., Akbaba Altun, S., \& Akgün, E. (2010). The strategies preschool teachers use when confronted with children's undesired behaviors. Elementary Education Online, 9(3), 971-979.

Yeşilyurt, H. (2017). İlkokul 4. sınıf öğrencilerinin görüşlerine göre istenmeyen öğretmen davranışları. Uluslararası Liderlik Eğitimi Dergisi, 1(1), 52-71.

Yıldırım, A., \& Şimşek, H. (2016). Sosyal bilimlerde nitel araştırma yöntemleri (10. baskı). Ankara: Seçkin Yayıncilik.

Yılmaz, N. (2012). Dersin akışını bozan istenmeyen davranışları yönetme stratejilerinin incelenmesi. Erzincan Eğitim Fakültesi Dergisi, 10(1), 1-38. 